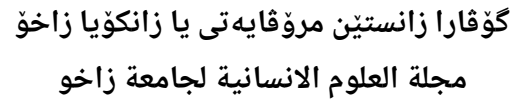

Humanities Journal of University of Zakho (HJUOZ)

Vol. 6, No. 2, pp. 611-623, June-2018

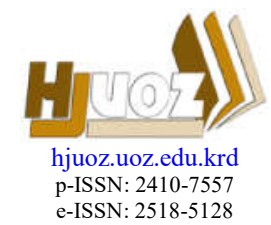

\title{
A Content Analysis of Euphemistic Strategies in The Evro Daily Newspaper
}

\author{
Fakhir Omar Mohammed ${ }^{1 *}$ and Suhayla H. Majeed $^{2}$ \\ ${ }^{1}$ Dept. of English Language, Faculty of Humanities, University of Zakho, Kurdistan Reign-Iraq. \\ ${ }^{2}$ Dept of English, Salahaddin University, Kurdistan-Region-Iraq.
}

\begin{abstract}
Received: 12. 2017 / Accepted: 09. $2017 /$ Published: 06. 2018 https://doi.org/10.26436/2018.6.2.514
\section{ABSTRACT}

The current paper tries to answer the question: What are the most important strategies for forming euphemisms on the word and sentence levels in the Kurdish daily newspaper, Evro? In order to reach accurate findings and results, the researchers followed the methodological procedures of Content Analysis (hence CA) by Berelson (1952) and Krippendorff (2003). Adopting a modified version of Warren's Model (1992) for the classification of euphemistic strategies, the data extracted from sample texts were processed and analyzed statistically via Excel sheets and SPSS software. The results obtained throughout this paper show that different euphemistic strategies within various news topics (i.e. politics, economy, death, religion, sports, etc.) manifest different percentages. On the word level, loan words show the highest percentage (40.3\%) from among all other strategies. In contrast, euphemisms related to reduplication strategy have the lowest percentage $(1.8 \%)$. With regard to other strategies, they are measured from highest to lowest, starting from understatement $(24.4 \%)$ followed by remodeling $(13.7 \%)$, acronyms $(7.6 \%)$, overstatement $(6.9 \%)$ and underspecification (5.4\%). On the sentence level, the passive voice strategy shows the highest percentage (30.4\%) from among all other strategies; however, euphemisms related to litotes strategy have the lowest percentage $(6.7 \%)$. With regard to the other strategies, they start from metaphors $(25.5 \%)$ followed by idioms $(25.2 \%)$, and finally downtoners $(12.1 \%)$. Finally, the use of euphemistic strategies in question was measured to test statistical differences between these strategies across specified semantic news topics, by means of a series of Chi-Squares and multiple comparison correlations, that were programmed and output by SPSS software 17.0. Statistically, there were moderate significant differences (i.e. $\mathrm{V}=.220, \mathrm{p}<0.05$ ) between and within all the news topics and euphemistic strategies.
\end{abstract}

Keywords: Euphemistic Strategies, Warren's Model, Content Analysis, Bahdini Dialect, Evro Newspaper.

\section{INTRODUCTION}

The concept of using euphemisms becomes more and more common in present day language. According to Hojati (2012: 1 ), euphemisms are frequently used by members of the society "to soften the impact of concepts with the potential to cause offense and social disapproval". This is because of the fact that words have great force, causing different reactions on one individual or one group (Baladze, 2013: 379). Euphemistic expressions are endemic in every society due to the fact that they are part of language customs. In communication, for better maintaining social relationship and exchanging ideas, people have to resort to a new different style of language, which can make distasteful ideas seem acceptable or even desirable (Baladze, 2013: 380). So, euphemisms are considered effective in the process of talking because they replace offending word forms by other word forms that express similar ideas and attitudes. Euphemistic expressions are used in both the spoken and written languages. Burchfield (1985: 29) argues that euphemisms are important part of every language since "a language without euphemisms would be a defective instrument of communication". Like many other languages, whether spoken or written, English and Kurdish are rich in the use of euphemisms and their negative, unpleasant, offensive counterparts, i.e., dysphemisms and taboos. Focusing on the written means of communication such as texts, it is important to say that the use of euphemistic expressions varies in degree according to different fields of discourse and the subject matters they are used in. In the current study, the term euphemism, as a general concept, is not taken into consideration. However, the focus is on the strategies that play an important role in the creation of euphemisms. In the "Euphemistic Strategies" part below, the researcher followed Allan and Burridge (1991) and Waren's Model (1992) as main references for the classification of euphemistic strategies.

\section{AIMS OF THE STUDY}

The current study was undertaken to analyze the use of euphemistic strategies in a local Kurdish newspaper (i.e. Evro) texts. Because there were no comparable studies in Kurdish linguistic literature to build upon, this study used basic, exploratory questions intended to yield statistical descriptive data. According to the nature of study and on the basis of the researcher's prior knowledge and study of euphemistic strategies, the following question is answered throughout the study:

- What are the most important strategies for forming euphemisms on the word and sentence levels in the Kurdish daily newspaper, Evro?

\section{HYPOTHESIS}

Following quantitative and qualitative statistical methods, the following research hypothesis was tested by applying different research tools to answer the research question mentioned above. At this point, this hypothesis was stated at the level of 0.05 , determining whether or not it was supported by the results:

\footnotetext{
${ }^{*}$ Corresponding author.

This is an open access under a CC BY-NC-SA 4.0 license (https://creativecommons.org/licenses/by-nc-sa/4.0/)
} 
There are statistical differences between the news topics covered by the daily newspaper, Evro, concerning the use of euphemistic strategies at both word and sentence levels.

Almost all languages have strategies where euphemisms are formed (Allan and Burridge, 1991:14). That is why; while hypothesizing that these strategies do not occur equally in all news topics, the data extracted from the sampling frame will be tested, coming to the right prediction.

\section{VALUE OF THE STUDY}

Recently, lots of studies have been written on the concept of euphemisms and euphemistic strategies in spoken contexts. However, research on the use of these strategies in establishing euphemisms in written texts is open to investigate. To the best of my knowledge, the study and analysis of euphemistic strategies in Kurdish daily newspapers has not been tackled before. Therefore, the current study sheds light on the use and availability of euphemistic strategies manifested in written discourse. In this way, it somehow serves the Kurdish linguistic studies.

\section{EUPHEMISTIC STRATEGIES}

There are different ways and strategies by which euphemisms are established in both spoken and written discourse. Here, in order to offer a fine-tuned analysis of euphemistic strategies in discourse, it is necessary to explore the forms euphemism can take at both word and sentence level. ${ }^{1}$ As proposed by Warren (1992), Allan and Burridge (1991:14) put a classification of these strategies into twelve types. They include: (1) loan words, (2) understatement, (3) overstatement, (4) underspecification, (5) remodelling, (6) reduplication, (7) acronyms, (8) litotes, (9) downtoners, (10) idioms, (11) metaphors and (12) passives. Before these strategies are talked about in more details, a brief explanation is given to Warren's Model (1992).

In the CA process, Warren's Model (1992) is adopted to figure the strategies forming euphemisms in the current study. Warren's Model is examined and the rules and categories suggested by this model are tested against euphemisms extracted from the newspapers. Warren's model is based on the idea that "novel contextual meanings", i.e. new meanings for words in a particular context, are constantly created in language. This creation is rule-governed and the acceptability of new meanings depends on the strength of links between the novel terms and their referents (Warren, 1992:130 and LinfootHam, 2005: 230). Such a relation results in the creation of euphemistic terms. It is seen that improvements are required of the model in order for it to account for all examples. That is why; a modified version of this model was proposed to encompass all of the euphemisms given in the sampling frame. It was necessary to subdivide Warren's Model into word and sentence levels so that quantitative research procedures were met as presented in the following figure:

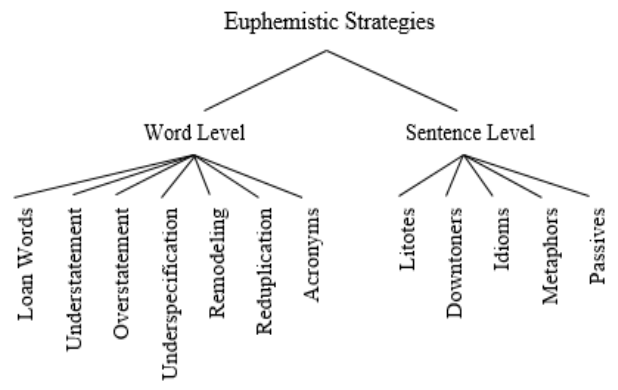

Figure 1: Euphemistic Strategies

5.1. Euphemistic Strategies at Word Level:
The majority of euphemistic items occur at word level, most notably through loan words, understatement, overstatement, underspecification, remodeling, reduplication and acronyms. They are explained in the following sub-sections.

\subsubsection{Loan Words:}

Languages include lots of words borrowed from other languages that can be used as means of forming euphemisms. For example, in English, the French word lingerie is a euphemistic form for underwear (Gomaa and Shi, 2012: 6). There are lots of loan words in the BD that are more euphemistic than native words. Ameen (2012: 31) mentions many examples of loan words from both English like سيّكس (sex), شيَّرم (shorts), شورت (sperm), etc., and Arabic including

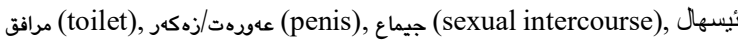
(diarrhea), غازات (gases), etc. They usually show a polite and euphemistic shape of communication.

\subsubsection{Understatement:}

The euphemistic substitutes which derive from understatement are "general-for-specific" euphemisms, expressing only part of the truth (Allan and Burridge 1991: 17-18 and Jackova, 2010: 29). In other words, understatement always leaves a room open for a more favorable interpretation of the distasteful topic being dealt with (Fernandez, 2014: 9). The word sleep for example means die and not bright means fool. In the BD, physical and personality traits are also stylistically changed by means of understatement (Bakhtiar, 2012: 11). For example, كيّ بيرت (with

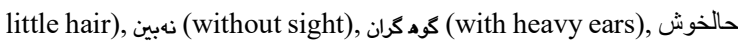
(with good condition) and دهست كورت (short-handed) are used for bald, blind, deaf, rich and poor respectively.

\subsubsection{Overstatement:}

Euphemisms can also be achieved by overstatement (also called hyperbole), that is, by "upgrading a desirable feature of the referent" (Fernandez, 2014: 10). Instances include fight to glory to refer to death and visual engineer to mean window cleaner. The same expressions can be found in the $\mathrm{BD}$. If a person is killed in war against enemies, we hear phrases or expressions stated by governmental personnel or politicians شوشهيد (martyr) and its equivalents such as خور كروبان (sacrificed himself), كهشته كارواني شهيدا (reached the martyrs' caravan), etc. The last example is outdated; it is no more used in media or among people.

\subsubsection{Underspecification:}

Sometimes a general term is used to be specified in its context to refer to a taboo subject and thus fulfil its euphemistic function (Allan, 2012: 12). This is called underspecification. ${ }^{2}$ In any language, the native speaker is able to select a different concept but related to the one usually symbolized by the lexical word. In the BD, instead of saying that someone is sick directly which is not good, happy news, people conceptualize other metonymic concepts to be used as يحي زهعيف بووى euphemisms. If a person is only sick, we say

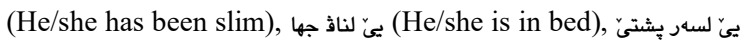
(He/she is on his/her back) or يحّ د خهستيدا ين (He/she is in hospital). Thought not being optimistic, these expressions show much sympathy and politeness. If a person is very sick, we usually use metonymic expressions such as هوستى و حهرد (bone and skin) or روح تيَ نهمايه (He/she has no soul). Finally, if a person is about to pass away, we hear expressions like يكّ لبهر مرنى (He/she is

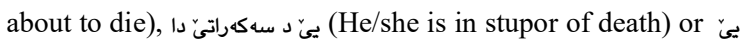
ل طه وارى (He/she is in emergency).

\subsubsection{Remodeling:}


Euphemisms are formed by another process called remodeling. It maintains "a greater or lesser degree of phonetic or orthographic similarity between the original and the novel form" (Allan, 2012: 2). Remodeling mainly works to avoid unpleasant and shameful topics such as profanity and sexual affairs in different languages. For example, in English, the word God is remodelled in euphemistic expletives in terms of various forms of oaths: Gad! Gog! Gosh! Golly! Goodness (knows)! (Good) gracious! For goodness' sake!, among others. In the $\mathrm{BD}$, one may hear euphemistic expressions remodelled from the direct use of the word خودئ (God) including (Allah) and رب العالمين and others. In the BD, people see the direct mentioning of مدمك (breasts) embarrassing. That is why; they use other words or expressions remodeled to avoid such embarrassment and shame: سينگ (breast), بهرسينگ (breast), سينگ و بهر (breast and chest), بهدهن (body), سنيث (cups), فنجان (apples), هرميك (pears), هنار (pomegranates), among many others. ${ }^{3}$

\subsubsection{Reduplication:}

Burridge (2012: 77) mentions the example of jeepers creepers as a reduplicated form of Jesus Christ. Reduplication means that euphemisms are formed by either the repetition of syllables or letters of words. This process commonly takes place in children's vocabularies related to bathroom and lavatory. For instance, pee-pee (piss), twiddle-diddles (testicles) and tuzzy muzzy (vagina) are frequently heard in the language of children. In the $\mathrm{BD}$, lots of words and expressions related to sexual harassment are used as reduplicated forms when talking to

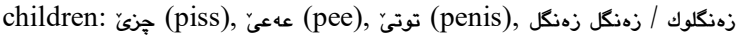

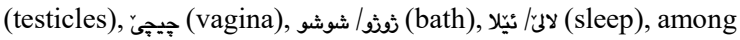
others.

\subsubsection{Acronyms:}

Acronyms, which are one form of abbreviations, are pronounced like words rather than a list of letters (Allan, 2012: 5).4 In English, acronym euphemisms are mostly used in military (SNAFU from Situation Normal All Fucked Up), computer sciences (RAM from Random Access Memory), health (AIDS from Acquired Immune Deficiency Syndrome), and so on. In the $\mathrm{BD}$, most of the acronyms used by people are related to various fields of life including academic circle, computer sciences, media, military, health, names of people, and the like (Mohammed and Mallow, 2012: 13-19). In politics, for example, acronyms like بֶدهـ (PDK = Democratic Party of Kurdistan), يهند (PUK = Patriotic Union of Kurdistan), (KSP = Kurdistan Socialist Party), etc. are used frequently.

\subsection{Euphemistic Strategies at Sentence Level:}

Many euphemisms occur at sentence level, most notably through litotes, downtoners, idioms, metaphors and passives. These techniques are discussed below.

\subsubsection{Litotes:}

Burridge (2012: 74) states that a special type of understatement is litotes, where the affirmative is expressed in terms of the denial of its opposite. For instance, in English the negative form not very bright can be used as euphemistic for stupid. In the analysis of some political speeches in different texts, Fernandez (2014: 10) claims that litotes is used to keep "verbal criticism within the limits of what one would conventionally consider polite behavior." The expression not making progress is euphemistically used instead of failed. In the $\mathrm{BD}$, if someone says به كهلكا ب زهحمهت (It is not so difficult.), it means ب سانهيه (It is easy.). Also, the expression نه خرابه (not bad) is a litotes that is used to mean باشه (good).

\subsubsection{Downtoners:}

Downtoners scale down the negative effect of the particular item they modify. 5 In other words, they tone down the statements presented in different topics like politics, sex and other social affairs. According to Fernandez (2005: 82), "any indirect strategy... gives rise to euphemistic speech acts directly motivated by conventions of tact and politeness". Lots of downtoning adverbs and phrases are found in the BD: بيجָك (slightly), وهكى (kind of, sort of), تا راديهكى (to some extent), تهريبهن (rather), ب زهمين (in the least), among many others.

\subsubsection{Idioms:}

Idioms can be defined as expressions whose meanings cannot be inferred from the meaning of its parts (Cruse, 1986: 37). In this sense, euphemisms and idioms share some common points. Like idioms, the type of lexical relation of euphemisms is being synonymous in nature. For instance, the expressions at rest and at peace, showing a more formal, polite social image of the person died, are synonymous to dead. In every language, there are lots of idiomatic euphemisms related to different topics especially parts of body. In the $\mathrm{BD}$, idioms in various contexts and social situations and fields help avoiding the use of taboos and disrespectful words and expressions. In the BD, idioms are related to head (سهر رهق hard head = obstinate), eye (جاثر ره black

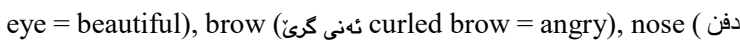

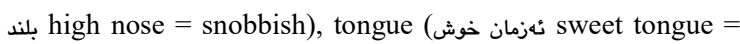
polite), neck (كهردن قاز goose neck = pretty), heart (دمثان خلخش good heart = happy), among many others (Baha'ddin, 2005: 12-20). However, it is very difficult to avoid speaking about unpleasant issues completely. For instance, the idiomatic expressions دراى (torn mouth = unable to keep secrets), حهفك ستوير (thick neck = rich), بهن كولند (zucchini squash height = short person) cannot be used as euphemisms in almost all contexts. They are usually replaced with more polite expressions such as ده بهرداى (open mouth = unable to keep secrets), دهولهمند (rich), دثن بكردي (short height $=$ little people) respectively. ${ }^{6}$ This reflects that not all idioms form euphemisms in the BD.

\subsubsection{Metaphors:}

There is a clear connection between euphemisms and metaphors, especially in terms of form and function. Euphemistic expressions might be presented in metaphorical forms to produce a wide variety of rhetorical effects. Euphemisms related to death are metaphorically conceptualized. Allan and Burridge (1991: 162) and Bultnick (1998: 44-45) have found and explicated a number of conceptual mappings for the consolatory metaphors of death: (1) Death is a journey, (2) Death is a joyful life, (3) Death is rest, (4) Death is a reward, (5) Death is the end, and (6) Death is a loss. In their book, Metaphors We Live By, Lakoff and Johnson (1980: 3-5) suggest that if "our conceptual system is largely metaphorical, then the way we think, what we experience, and what we do every day is very much a matter of metaphor"?

In Kurdish, a corpus of about fifty samples of euphemistic expressions for death has been drawn by Shekhany (2006:341-5). ${ }^{8}$ The following expressions are metaphorically conceptualized as euphemisms in the BD: جور (went), ومغرك (t) (migrated), وهنما (nor more present), وهناركر (travelled), وناتكر :

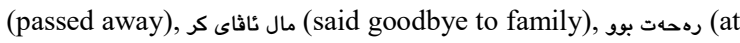

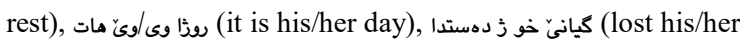
soul), جوو بهر رهمما / دلوثانيا خودي (went to be under the Mercy of God), and the like.

\subsubsection{Passives:}


The use of passive constructions is one remarkable means of establishing formal, polite and euphemistic expressions. Fox (2001: 48) states that euphemisms success in baffling the mind of listener easily when passive voice is reflected in language. This means that a specific group of people, especially politicians, attempt to minimize responsibility for actions taken (Fernandez, 2014: 12). The following sentence from the BD is in the passive voice and hence it seems to be more polite and euphemistic: ب توندى نهرازيبون لسهر هاته دياركن (It has been rejected severely.)

\section{METHODOLOGY}

The content analysis (hence, CA) method by Berelson (1952) and Krippendorff (2003) was used to find, interpret and analyze the data extracted from sample texts.

The most frequently used technique in analyzing written documents is the CA method (Robson, 2002: 349). The CA, which is becoming one of "the fastest-growing methods" in quantitative research, is a text interpretation method for summarizing any form of content by counting various aspects of the content (Luke et al, 2011: 77). The CA is broadly a strict and systematic set of procedures for the rigorous analysis, examination and verification of the contents of written data (Flick 1998: 192 and Mayring 2004: 266). Here, many researchers defined the $\mathrm{CA}$ according to different views. Berelson (1952: 18) defined the CA as "a research technique for the objective, systematic, and quantitative description of the manifest content of communication". ${ }^{9}$ This means that the CA is a research method for "defining, measuring, and analyzing both the substance and meaning of texts" (Beck and Manuel, 2008). Focusing on the validity and reliability of the sample, Krippendorff (2003: 18) defines the CA as "a research technique for making replicable and valid inferences from texts (or other meaningful matter) to the contexts of their use". The same idea was presented by Weber (1990: 9) saying that the $\mathrm{CA}$ is "a research method that uses a set of procedures to make valid inferences from text". According to Berelson (1952: 11) and Riffe et al. (2014: 30), though the CA methodological tool is time consuming, it offers several advantages as listed below: - It looks directly at communication via texts, providing valuable linguistic, social and cultural insights over time.

- It can allow for both quantitative and qualitative operations to assess, analyze and understand texts.

- It describes the characteristics of any content especially that of newspapers, making inferences about causes and effects of such content.

All in all, the objective of the CA is "to convert recorded raw phenomena into data", which can be treated in essentially a scientific manner so that a body of knowledge is built up (Prasad, 2015: 9).

\subsection{The Procedures of the Content Analysis:}

As organized by Chadwick et al (1984: 248-259), Krippendorff (2003: 83-87), Neuendorf and Skalski (2010: 12-13) and Denscombe (2010: 281-282), the process of the CA goes through six logical and relatively ordered stages: (1) unitizing, (2) sampling, (3) categorizing, (4) coding, (5) inferring and (6) narrating. ${ }^{10}$ In the light of analyzing the data taken from the Evro daily newspaper ${ }^{11}$, the researcher did a CA according to the above-mentioned stages:

1. Unitizing: It is simply "the systematic distinguishing of segments of texts" (Krippendorff, 2003: 83). This can be achieved by "making a clear statement of the research question or objective" (Prasad, 2015: 9). Therefore, the selection of topic should be one that can be answered by analyzing the appropriate communication content. The content (i.e. words, phrases, sentences) selected for the purpose of the current study covers the strategies by which euphemisms are formed in Evro newspaper.
2. Sampling: It is "a subset of units from the entire population being studied" (Riffe et al, 2014: 71). The usual goal of sampling, the smaller group of units actually measured, is to represent the population, the larger group of units about which inferences are to be made (Utts and Heckard, 2007: 72-73). In doing a textual CA for the Evro daily newspaper, some issues of this newspaper were randomly selected starting from January to December, 2016, to represent the whole population. The researcher followed what is called stratified constructed week sampling, which is created by randomly selecting an issue for each day of the week (Riffe et al., 2014: 85). That is, one constructed week $(\mathrm{CW})$ is created by selecting the Saturday, Sunday, Monday and Tuesday issues from successive weeks in one month, and the Wednesday, Thursday and Friday issues from successive weeks in the following month. In this case, one $\mathrm{CW}$ is formed for a seven-day operation daily newspaper. The researcher in the current study used six CWs to work as a sampling frame. In case of Evro, one $\mathrm{CW}$ consists of five issues and the total number of issues selected was 30 in number because it has five-day operation circulation starting from Sunday until Thursday. This means that the total number of all issues selected from exactly a oneyear population of 239 issues from the newspaper was 30 issues. ${ }^{12}$ The sample size percentage is shown in the following formula:

$\%$ of sample size $=\frac{\text { No.of issues in the sample }}{\text { No.of issues in the population }} \times 100$

Hence, according to the above formula, the sample size percentage can be linearly calculated as: $30 / 239 \times 100=12.5 \%$. Such percentage is high enough to conduct a CA for the target population. In other words, $12.5 \%$ is a percentage that makes the sample size valid and acceptable for processing the CA in quantitative research studies (Neuendorf and Skalski, 2010: 13).

The CW sampling method has long been used by many researchers because of the traditional importance of daily newspapers as journalism mass media. Luke et al (2011: 78) claims that the use of $\mathrm{CW}$ method is very useful because it actually "accounts for cyclic variation of news content". According to Riffe et al (2014: 84), these researchers have "concentrated on efficiency of sampling for inference to a typical level of content". In their book titled Analyzing Media Messages, Riffe et al (2014: 85), with the assistance of five coders, presented the nature of efficient stratified sampling methods for inferring to content in a table, claiming that two CWs can well represent one-year population of a daily newspaper and nine CWs for five years. The efficiency of selecting two CWs for representing a year's content was used by Stempel (2003: 212) and Weaver (2009: 34-35) long before when they studied the front-page articles of a six-day operation newspaper in England and the front-page stories of several newspapers in the USA respectively. Luke et al. (2011), with the assistance of three coders, examined sampling in daily newspapers for health stories concluding that it would take six CWs, rather than two, to find a representative sample of health stories in one-year period. Even within these six CWs, these researchers randomly selected two issues of newspapers from each $\mathrm{CW}$ for extracting and recording examples of the phenomenon under investigation. This means, the total number of CWs selected was six for counting data and finding frequencies while the total number of $\mathrm{CWs}$ for recording examples was two. The reason why six CWs were used for the purpose of analysis is due to two important factors: the level of confidence and margin of error, which is "a measure of how much the sample may differ from the population at a certain level of confidence" (Riffe et al, 2014: 141). As a fact of statistical calculations, the margin of error depends on the sample size: the bigger the sample size the smaller the margin of error (Utts and Heckard, 2007: 75-76). For social science purposes (the analysis of euphemistic strategies in Evro in the 
current study), the conventional level of confidence is almost always at $95 \%$. The following equation, taken from Utts and Heckard (2007: 76) calculates the margin of error between the sampling frame and one-year population of the sample content under investigation:

Margin of Error $=\frac{1}{\sqrt{n}}$ where $\mathrm{n}$ represents the sample size. For example, with a sample of 30 randomly chosen issues of the whole population (exactly 239 issues), we will usually get an estimate that is accurate to within $1 / \sqrt{3} 0=1 / 5.47=0.18=18 \%$ of the truth. This indicates that the amount by which the sample proportion differs from the true population proportion is equal or less than this quantity (i.e. $18 \%$ ) in at least $95 \%$ of the entire corpus. The following table shows the six CWs and exact dates of Evro's corpus:

\begin{tabular}{|c|c|c|c|c|c|c|c|c|c|c|c|c|c|c|c|c|c|c|c|c|c|c|c|c|c|c|c|c|c|c|}
\hline & \multicolumn{5}{|c|}{ CW 1} & \multicolumn{5}{|c|}{ CW 2} & \multicolumn{5}{|c|}{ CW 3} & \multicolumn{5}{|c|}{ CW 4} & \multicolumn{5}{|c|}{ CW 5} & \multicolumn{5}{|c|}{ CW 6} \\
\hline & 芸 & $\stackrel{5}{2}$ & $\stackrel{0}{=}$ & $\overline{0}$ & 害 & 击 & है & $\stackrel{0}{=}$ & के & 害 & ڤ & है & : & 苟 & 氧 & 气 & $\bar{\Sigma}$ & 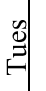 & B & 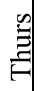 & : & है & $\stackrel{0}{=}$ & $\frac{\vec{D}}{3}$ & 恖 & $\Xi$ & है & $\stackrel{\mathscr{\varrho}}{\leftrightarrows}$ & 3 & 占 \\
\hline 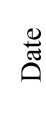 & = & $\underset{\Xi}{\stackrel{\infty}{\Xi}}$ & $\begin{array}{l}N \\
0 \\
0 \\
0\end{array}$ & $\begin{array}{l}0 \\
0 \\
0\end{array}$ & 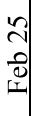 & 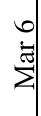 & \begin{tabular}{l}
$\infty$ \\
$\stackrel{\infty}{N}$ \\
\multirow{\Xi}{*}{}
\end{tabular} & $\begin{array}{l}0 \\
= \\
0 \\
0\end{array}$ & 워 & 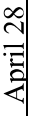 & 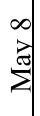 & \begin{tabular}{l} 
సे \\
\multirow{3}{2}{}
\end{tabular} & 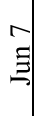 & 号 & 气ิ & 3 & $\Xi$ & 촐 & 긍 & 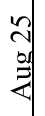 & $\begin{array}{l}+ \\
+ \\
\text { 离 }\end{array}$ & 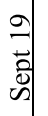 & $\begin{array}{l}+ \\
⿱ \\
0\end{array}$ & $\frac{N}{5}$ & 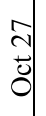 & $\begin{array}{l}0 \\
z \\
z\end{array}$ & $\begin{array}{l} \pm \\
\vec{z} \\
z\end{array}$ & 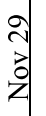 & $\begin{array}{l} \pm \\
\Xi \\
\Xi\end{array}$ & $\begin{array}{l}\stackrel{2}{\hat{D}} \\
\stackrel{0}{0}\end{array}$ \\
\hline
\end{tabular}

Table 1: The CWs and Exact Dates of the Evro Daily Newspaper Corpus

3. Categorizing: Before beginning any analysis, the researcher prepared well for conducting the CA process. First, one issue from each newspaper was randomly taken in order to read and review the content material of the population. It was seen that the formation of euphemisms depends on different linguistic strategies. Further, before starting the coding process, the researcher prepared the following to serve the "need for efficient representations, especially of large volumes of data" (Krippendorff, 2003: 84):

- Pre-defined research questions,

- Important terms and concepts related to euphemistic strategies,

- An Excel coding sheet to record frequencies of euphemistic strategies (see Appendix II,), and

- SPSS software, version 20, for analyzing the data into statistical descriptions.

Categorizing is very important because developing a category system to classify the body of text is the heart of processing any CA.

4. Coding: It is considered the most important stage in the CA. One reason for this analytical component is the need "to create durable records of phenomena" (Krippendorff, 2003: 84). In the process of coding, the researchers coded the material separately. In doing the coding process, the coders read down the content material and fell out the coding sheet, looking for the euphemistic strategies at word and sentence levels. Hence, for the purpose of the current study, the coders recorded all the material according to the six CWs (i.e. CW1, CW2, CW3, CW4, CW5 and CW6). Further, coding was based on the frequency of items (i.e. euphemisms under certain news topics relevant to the newspaper topics). The content was coded by reading through the text and manually writing down item occurrences on the previously prepared coding sheet. For the purpose of study, the researchers developed a coding scheme of abbreviations together with their equivalent numbers to understand immediately the issue that they denote. These codes, as shown in Appendix III, include euphemistic strategy units (hence ES) starting from 1 to 12 and news topics from 1 to 8 (as NT). As stated by Denscombe (2010: 282), these codes are usually written on the text first, then they are entered via some excel sheets to show the occurrences, frequencies and total number of all items coded (see Appendix II). During the coding process, an important methodological issue was taken into consideration, that is, checking reliability of coding. Reliability in quantitative research is essentially "a synonym for dependability, consistency and replicability over time, over instruments and over groups of respondents" (Cohen et al, 2007: 146). Coders must be reliable, i.e. they must apply the categories and look for data in the same way. According to Landis and Koch (1977: 161) and Prasad (2015: 14), it is desirable to have, even in a small-scale study, more than one coder to independently code the units and to check what is called the interrater reliability. ${ }^{13}$ It is statistically measured by Cronbach alpha coefficient calculated by SPSS at the click of a button. The interpretation of alpha statistically ranges from 0.0 to 1.0. A more complete list of how alpha might be interpreted is given in the following table (Cohen et al, 2007: 506):

\begin{tabular}{|l|l|l|l|l|l|}
\hline \multicolumn{1}{|c|}{ Table 2: Interpretation of Cronbach alpha } \\
\hline & Low & Minimal & Reliable & $\begin{array}{l}\text { Highly } \\
\text { Reliable }\end{array}$ & $\begin{array}{l}\text { Very Highly } \\
\text { Reliable }\end{array}$ \\
\hline Alpha & $<0.60$ & $0.60-0.69$ & $0.70-0.79$ & $0.80-0.90$ & $>0.90$ \\
\hline
\end{tabular}

The researchers checked reliability by calculating the coded data of only one $\mathrm{CW}$ taken from the sample. According to the alpha scale, the inter-item correlations showed reliable and valid results between the coders. The following table shows stability and consistency of test material:

Table 3: Reliability Statistics

\begin{tabular}{|c|c|}
\hline Cronbach's Alpha & No. of Coders \\
\hline .835 & 2 \\
\hline
\end{tabular}

The correlation coefficient is .835 as shown in the above table, representing the reliability and validity of model assumptions. 
In other words, the coding process is highly reliable according to the alpha scale. Obviously, there were no such differences between the coders.

5. Inferring: This stage "bridges the gap between descriptive accounts of texts and what they mean, refer to, entail, provoke or cause" (Krippendorff, 2003: 85). This is a crucial step where the data are interpreted and analyzed after the validity of sample size $(12.5 \%)$ and interrater reliability of coding (.835) were manifested. Analysis was achieved according to (1) finding statistical descriptions for the euphemistic strategies and (2) presenting the data statistically via tables and charts. It was suggested that a frequencies procedure to be run at the very beginning of analysis on the euphemistic strategies. Such a procedure was helpful to "see the distribution of some variables the minimum, maximum, mean, median, standard deviation", etc. (Lynch and Peer, 2002: 29).

6. Narrating: The researchers examine the data and attempt to draw whatever conclusions and generalizations are possible. Simply, findings and conclusions are interpreted and reported, depending on accurate analytical measurements. According to Riffe et al (2014: 51), "measurement failure creates unreliable and invalid data that lead to inaccurate conclusions". Here, in doing a CA for written texts, establishing adequate interrater reliability is a key part of assessing measurement success.

\section{DATA ANALYSIS AND DISCUSSION}

As mentioned above, the data extracted from the sample, which depend on the CA and Warren's Model (1992) procedures, are statistically analyzed by using SPSS software and Excel sheets. The frequencies, percentages, means (i.e. M) and standard deviations (i.e. SD) of euphemistic strategies were statistically described for word and sentence levels separately. Then all the strategies in the whole news topics appeared in the corpus were analyzed altogether. The results of the analysis are presented in the following sub-sections below.

\subsection{Frequency of Using the Euphemistic Strategies at the Word Level}

The frequency of using the euphemistic strategies at word level in different news topics is presented in Figure (2) below:

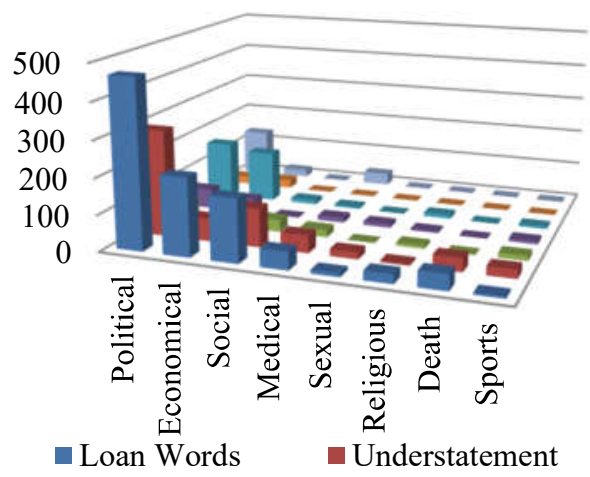

Figure 2: Frequency of Using the Euphemistic Strategies at the Word Level

On the word level and from the total of 2461 euphemistic words extracted and coded across different news topics from the sampling frame, i.e. Evro daily newspaper, loan words $(\mathrm{M}=123.87, \mathrm{SD}=158.22)$ showed the highest percentage $(40.3 \%)$ from among all other strategies. In contrast, euphemisms related to reduplication $(\mathrm{M}=5.63, \mathrm{SD}=10.44)$ strategy had the lowest percentage $(1.8 \%)$. With regard to the means and percentages of the other strategies as manifested in Table 5.1 below, they were measured from high to low ranking: understatement $(\mathrm{M}=75, \mathrm{SD}=93.76)$, followed by remodeling
$(\mathrm{M}=42, \quad \mathrm{SD}=66.93), \quad$ acronyms $\quad(\mathrm{M}=23.25, \quad \mathrm{SD}=45.75)$, overstatement $\quad(\mathrm{M}=21.25, \quad \mathrm{SD}=19.93)$ and finally underspecification $(\mathrm{M}=16.62, \mathrm{SD}=19.84)$. These frequencies show that Evro texts contain a remarkable amount of loan words as euphemisms used in place of other words and expressions which seem to be not proper when mentioned in formal, academic written discourse. Table (4) below shows the frequencies, percentages, means and standard deviations of the euphemistic strategies on the word level:

Table 4: Frequencies, Percentages, Means and Standard Deviations of the Euphemistic Strategies at the Word Level

\begin{tabular}{|c|c|c|c|c|c|}
\hline $\begin{array}{c}\text { Strategies on the Word } \\
\text { Level }\end{array}$ & Mean & N of Topics & Std. Deviation & Sum & $\%$ \\
\hline Loan Words & 123.88 & 8 & 158.220 & 991 & $40.3 \%$ \\
\hline Understatement & 75.00 & 8 & 93.760 & 600 & $24.4 \%$ \\
\hline Overstatement & 21.25 & 8 & 19.934 & 170 & $6.9 \%$ \\
\hline Underspecification & 16.63 & 8 & 19.849 & 133 & $5.4 \%$ \\
\hline Remodeling & 42.00 & 8 & 66.939 & 336 & $13.7 \%$ \\
\hline Reduplication & 5.63 & 8 & 10.446 & 45 & $1.8 \%$ \\
\hline Acronyms & 23.25 & 8 & 45.756 & 186 & $7.6 \%$ \\
\hline Total & 43.95 & 56 & 82.376 & 2461 & $100.0 \%$ \\
\hline
\end{tabular}

In general, loan words (991 occurrences) in the Kurdish culture usually show a polite shape of communication. Examples taken from the sample are borrowed from different languages such as English, Arabic, Turkish, Italian, etc.: جيويوليتيك (geopolitical), ديفاكتو (de facto), حكومهت (government), بةلانس (balance), شر عيةت (legislation), رهئى (opinion) , فهوزا (chaos), تيورست (terrorist),

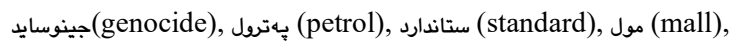

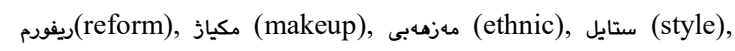
among hundreds of others. The use of loan words in written 
discourse goes back to factors like (1) the effect of neighbor languages on the native language (i.e. the BD here) and (2) the writer's educational background.

Among all word level strategies, reduplication (i.e. the repetition of syllables or letters of words) ranked the least frequent euphemistic resource. It recorded 45 occurrences only from all the CWs coded. This is due to the fact that articles in daily newspapers are written to be very formal and polite, and reduplicated words and expressions seem to be informal. Examples of euphemistic reduplication include ململاني (struggle), كيموكورى (lack of something), كيروكرفت (problems),

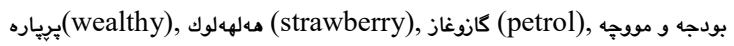
(income), هدرارى و نهدارى (poverty), among others.

Concerning understatement, it usually leaves a room open for a more favorable explanation of certain distasteful topics (Fernandez, 2014: 9). This is what writers exactly do. An interesting use of euphemistic understatement $(600$ occurrences) appears in the examples ريكخراوا تيرورستى (a terrorist organization), توركومانيّن شوفينى (chauvinistic Turkmen), etc. They are purposively used by writers to belittle these concepts in view of readers. Many examples are used ironically to lessen the impact on public opinion of various topics. For instance, the

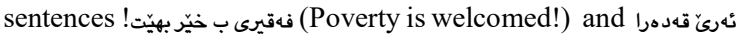
مه بوحيى يه؟ (What is our fate used for?) are ironically used to show a pessimistic view of life topics and concepts. Other examples such as كاريّن خراب (bad deeds), دولهمهند (rich), رجيم (weight loss), كوردوفوبيا (Kurd phobia), etc., are indirectly used to work as euphemisms in order to understate unpleasant realities. Simply, writers try their best to speak around a given word, implying it without saying it (Fernandez, 2014: 10).

Although these strategies overlap in some news topics, the frequency of euphemistic remodeling comes in the third rank

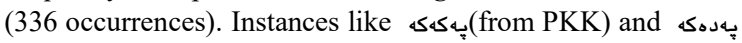
(from PDK) are remodeled forms of acronyms, which are considered other devices of establishing euphemisms in the target sample. Almost all examples of remodeling coded and extracted manifest "a phonetic or orthographic similarity between the original and the novel form" (Allan, 2012: 2). Novel forms such as حوكمهت (government), مهزهمبيى (ethnic)

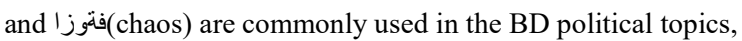
referring to Arabic original forms. Words including شوتكن (shooting), بهترول (petrol), بايكوت (boycott), بودجه (budget), بروك (net), (trade mark), نيوز (news), among others, are borrowed from other foreign languages but somehow remodeled. The use of euphemistic remodeling, as shown in the mentioned examples, is not limited to nouns only. The remodeled word نةكةز (to text) is a verb; it shows a high level of educational background.

As for acronyms (186 occurrences), the statistical results showed that most of euphemistic acronyms were presented in military, politics and health topics. For instance, an abbreviation such as (Dr.) is highly noticed in the Evro sample to politely show the academic rank of personalities. In politics, acronyms like بهدهك (PDK = Democratic Party of Kurdistan) and ينة (PUK = Patriotic Union of Kurdistan) are used frequently. However, unlike the English language, $P D K$ or PUK are not used as acronym euphemisms among the majority of people, especially politicians. Instead, underspecified words such as بپارتى (party) and يهكيتى (union) are used because these latter forms are more polite, formal and respectful. When a PDK member says بֶ (party), he/she feels to belong to their political party, PDK. As an abbreviation, i.e. PDK, it is usually heard from people who are not PDK members or do not show any intimacy to PDK.

Euphemisms can also be achieved by overstatement strategy (170 occurrences), that is, by upgrading a desirable feature of the referent. This device manifested in the phrases ئهفانهيا داعش (ISIS myth), خيانهتا ديركى (historical treason), and words like ميّرخاس (brave), شهرهز (smart), دردار (tough) among lots of others. Finally, many examples of underspecification (totally 133 in number) were used as euphemisms. Instances included دوثمن (enemy) to refer to عهرهب و تورك و فارس (Arabs, Turks and

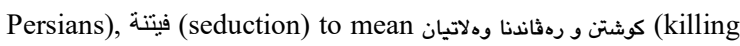
and kidnapping citizens), the abbreviation GIZ to talk about a German organization, خيّزانهكا ساخله (a healthy family) to stand for هـثريني (marriage), and so on.

\subsection{Frequency of Using the Euphemistic Strategies at the Sentence Level}

Euphemisms did not occur at the word level only. However, different euphemistic strategies were vividly used at the sentence level as well. The frequency of using the euphemistic strategies at sentence level in different news topics is presented in the following figure:

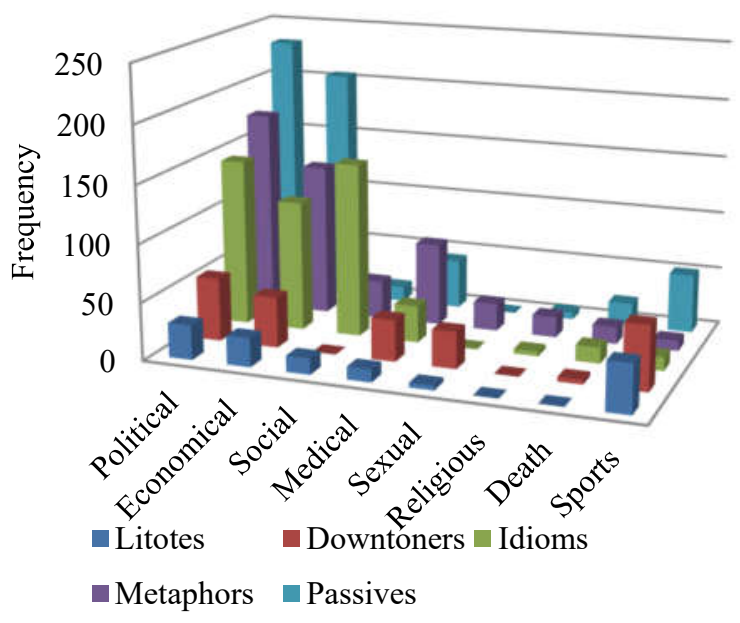

Figure 3: Frequency of Using the Euphemistic Strategies at the Sentence Level 
From the total of 1872 euphemistic examples at the sentence level, passives showed the highest percentage $(M=71.25$, $\mathrm{SD}=92.80$ ) from among all other strategies. In contrast, euphemisms related to litotes strategy had the lowest percentage $(M=15.75, S D=15.29)$. With regard to the means and percentage of the other strategies, they were measured from high to low ranking, starting from metaphors $(\mathrm{M}=59.75$, $\mathrm{SD}=62.06)$ followed by idioms $(\mathrm{M}=58.87, \mathrm{SD}=65.73)$, and finally downtoners $(\mathrm{M}=28.37, \mathrm{SD}=23.88)$. Table (5) shows the frequencies, percentages, means and standard deviations of the euphemistic strategies at the sentence level:

Table 5: Frequencies, Percentages, Means and Standard Deviations of the Euphemistic Strategies at the Sentence Level

\begin{tabular}{|c|c|c|c|c|c|}
\hline $\begin{array}{c}\text { Strategies on the } \\
\text { Sentence Level }\end{array}$ & Mean & N of Topics & $\begin{array}{c}\text { Std. } \\
\text { Deviation }\end{array}$ & Sum & $\%$ \\
\hline Litotes & 15.75 & 8 & 15.295 & 126 & $6.7 \%$ \\
\hline Downtoners & 28.38 & 8 & 23.880 & 227 & $12.1 \%$ \\
\hline Idioms & 58.88 & 8 & 65.732 & 471 & $25.2 \%$ \\
\hline Metaphors & 59.75 & 8 & 62.069 & 478 & $25.5 \%$ \\
\hline Passives & 71.25 & 8 & 92.807 & 570 & $30.4 \%$ \\
\hline Total & 46.80 & 40 & 60.097 & 1872 & $100.0 \%$ \\
\hline
\end{tabular}

In the following passive voice forms (570 occurrences), it seems that the speaker minimizes the responsibility of specific actions taken:

1) كرينا كازا سروشتى و بهنترولن هاتيه بهيداكن (The purchase of natural gas and petrol has been found.)

2) نابيت بهرلهمان زكار بكهثيت، بهلكو دثيّت بهيّه كاراكرن (The Parliament shouldn't be deactivated; it should be activated)

Also, at the sentence level, 478 examples were found as metaphor euphemisms. The following sentences were use metaphorically in order to rhetorically affect the reader:

3) توركمان دثى خهندها كوردستاني نه (The Turkmen are against the Kurdistan Trench.)

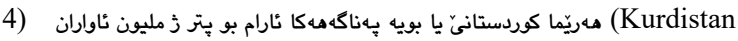
Region has become a peaceful shelter for more than million refugees.)

In the first example above, Kurdistan Trench is indirectly and metaphorically used as an underspecified euphemistic expression to mean Kurdistan borders. The expression peaceful shelter attracts the readers' attention to conceptually feel that Kurdistan is secure and peaceful.

Within various news topics (i.e. politics, economy, religion, sports, etc.), idiomatic euphemisms (471 occurrences) were used to avoid the use of taboos and disrespectful ideas: ثشت

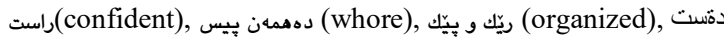

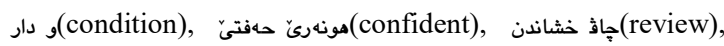
كورتئينان(lack), etc. These examples are more figurative and more euphemistic when used in complete sentences.

To tone down offensive, sad, unwanted topics, downtoners (227 occurrences) can be used as euphemisms in written discourse. In the following sentence, the word رهنك (maybe) is used to show that the writer, who does not want to talk about such an accident, is not sure of the car accident cause:

5) ترومبيّل وهركهريا و رهنكه ذزئهنجامي بلهز ماثوتنيّ بيت (Maybe the car crashed because of speed.)

Sometimes the negative form of affirmative expressions is used to show higher degrees of formality and politeness. Hence, the use of litotes (126 in number) in Evro daily newspaper articles is a means of making the written discourse more euphemistic. Examples such as سهرنهكرتن(not successful), بيّ زارو (with no kids), (not present) and نه ديار (no justice) are negatively used to mean failure, sterile, missing and unfairness respectively. The denial form of the following examples is actually an indirect way of talking about different topics:

6) كوتارا سياسى سهركهنتى نابيت (Political speech will not be successful.)

7) ب تايبهت ئهكه نئه جوريخ مكياثى ماركه نهبيت (especially if that type of make-up is not a trade mark)

8) نهبوونا كيانيّ ههثركييّ (the lack of struggle spirit)

9) ديسان نوشدار دباشن و كيّم نينن (Doctors are good and they are not few.)

\subsection{Correlations between the Word and Sentence Levels in News Topics}

On conducting a CA for the target sample, the results showed that euphemistic strategies at word level generally presented higher percentages than those at sentence level except in medical, sexual and sports news topics. In the following figure, the frequency of using euphemistic strategies across different news topics is clear: 


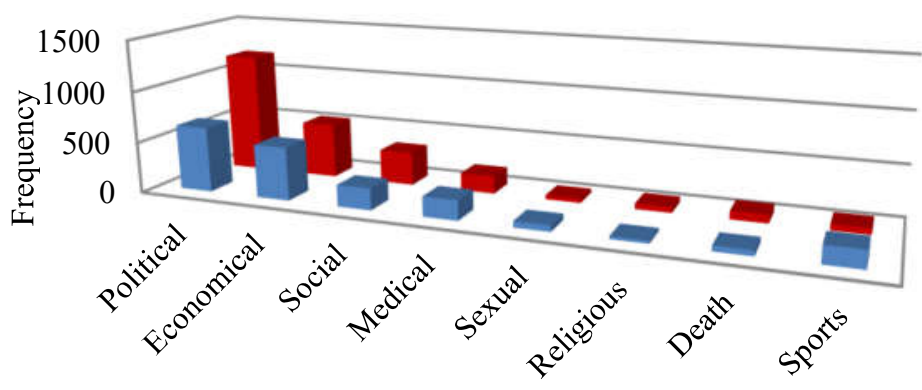

घ Sentence Level — Word Level

Figure 4: The Euphemistic Strategies at the Word and Sentence Levels in NewsTopics

As it is shown in the above figure, the political news topic presents a higher percentage of euphemistic strategies at the word level $(48.07 \%, 1183$ occurrences) than that at the sentence level $(34.02 \%, 637$ occurrences). The lowest percentages of strategies at word and sentence levels were found in the sexual topic $(1.7 \%, 42$ occurrences) and religious topic $(1.49 \%, 28$ occurrences) respectively. This reflects that the daily Evro newspaper is mostly written for political purposes more than having social orientations.

7.4. Nominal Measures of Statistical Correlation between the Euphemistic Strategies and News Topics

According to the statistical association between the euphemistic strategies (dependent variables) between the news topics (i.e. independent variables), the data were analyzed by means of a series of Chi-Square and multiple comparison correlations that were programmed and output by SPSS software.

Chi-Square correlations were used in the current study because the data are nominal in nature and defined as categorical variables. Chi-Square indicates "the statistical significance of the relationship between two variables measured at the nominal level" (Riffe, et al, 2014: 151). Within the Chi-Square test, it was very helpful to refer to Cramer's V (value), which indicates how statistically significant the association between nominal variables. This is calculated "with values ranging from 0 to a perfect 1.0" (Riffe, et al, 2014: 152). A more complete picture of how the magnitude of association might be described is given in the following table (Rea and Parker, 1992: 203):

Table 6: Description of Cramer's V

\begin{tabular}{|l|l|l|l|l|l|l|}
\hline & Negligible & Weak & Moderate & $\begin{array}{l}\text { Relatively } \\
\text { Strong }\end{array}$ & Strong & $\begin{array}{l}\text { Very } \\
\text { Strong }\end{array}$ \\
\hline Cramer & $.00-.10$ & $.10-.20$ & $.20-.40$ & $.40-.60$ & $.60-.80$ & $.80-1.00$ \\
\hline
\end{tabular}

Before running the Chi-Square test for manifesting statistical significance, it was very necessary to weight the distribution of all cases in order to show the valid cases. All the cases selected for analysis were interpreted as valid $100 \%$. This is clearly presented in the following table run by Chi-Square test:

Table 7: Case Processing Summary

\begin{tabular}{|c|c|c|c|c|c|c|}
\hline \multirow{2}{*}{} & \multicolumn{4}{|c|}{ Cases } \\
\cline { 2 - 7 } & \multicolumn{2}{|c|}{ Valid } & \multicolumn{2}{c|}{ Missing } & \multicolumn{2}{c|}{ Total } \\
\cline { 2 - 7 } & $\mathrm{N}$ & Percent & $\mathrm{N}$ & Percent & $\mathrm{N}$ & Percent \\
\hline Weight * Topics & 4333 & $100.0 \%$ & 0 & $0.0 \%$ & 4333 & $100.0 \%$ \\
\hline
\end{tabular}

where $\mathrm{N}$ represents the number of cases in the sample. Hence, in order to compare the frequency of the use of euphemistic strategies in all the news topics in the Evro daily newspaper, a Chi-Square test was calculated. The results were shown as $\mathrm{X}^{2}$
$(77, \mathrm{~N}=4333)=.220, \mathrm{Sig} .=.000, p<.05$. This means that the mean difference was significant at the .05 level between and within all the news topics and euphemistic strategies. This is very clear in Table (8) below:

Table 8: Chi-Square Tests

\begin{tabular}{|c|c|c|c|}
\hline & Value & Df & Asymp. Sig. (2-sided) \\
\hline Pearson Chi-Square & $1470.959^{\mathrm{a}}$ & 77 & .000 \\
\hline Likelihood Ratio & 1389.644 & 77 & .000 \\
\hline Linear-by-Linear Association & 27.884 & 1 & .000 \\
\hline N of Valid Cases & 4333 & & \\
\hline
\end{tabular}

6 cells $(16.7 \%)$ have expected count less than 5 . The minimum expected count is .87 . Not assuming the null hypothesis.

The Chi-Square test is valid for calculating the data extracted because the expected counts smaller than 5 presented $16.7 \%$ of the total cells. This means that all the other expected counts are larger than 5, showing statistical association between the euphemistic strategies and news topics.
The strength of association between the categorical variables (i.e. news topics and euphemistic strategies) was measured as $\mathrm{V}=.220$, presented in the following table under the value of Nominal by Nominal, Cramer's V: 
Table 9: Symmetric Measures

\begin{tabular}{|l|l|c|c|}
\hline \multicolumn{2}{|c|}{} & Value & Approx. Sig. \\
\hline \multirow{2}{*}{ Nominal by Nominal } & Phi & .583 & .000 \\
\cline { 2 - 4 } & Cramer's V & .220 & .000 \\
\hline N of Valid Cases & 4333 & \\
\hline
\end{tabular}

According to the statistical descriptives, Sig. differences and strength of association, the results obtained were in agreement with the hypothesis proposed. As a result, whenever the semantic field of news topics changes, it has a moderate influence on changing the numerical statistics of the euphemistic strategies. Here, since the p-value of an observed effect is less than the significance level (i.e. Sig. $=0.00, p<$ .05 ), it can be concluded that there is enough evidence to support the claim that the observed effect of the sample reflects the characteristics of the whole population moderately $(\mathrm{V}=$ .220 ). Here, it is reasonable to claim that the various news topics written for the Evro daily newspaper are considered moderately euphemistic because writers and reporters use a moderate amount of euphemistic strategies on both the word and sentence levels.

\section{CONCLUSIONS}

The Evro sample presented different frequencies and percentages of the strategies that form euphemisms at both the word and sentence levels. Due to the effect of neighbor languages on the native language (i.e. the $\mathrm{BD}$ here) and the educational background of writers and reporters who work for the Evro, loan words, at the word level, showed the highest percentage $(40.3 \%, 991$ occurrences). The reduplication strategy had the lowest percentage $(1.8 \%, 45$ occurrences $)$ because reduplicated words to an extent seem to be informal. At the sentence level, passives were found to have the highest percentage (30.4\%, 570 occurrences). In contrast, euphemisms related to litotes strategy had the lowest percentage $(6.7 \%, 126$ occurrences). This minimizes the responsibility of specific actions fulfilled by individuals, politicians, political parties, or governments. In general, and at the two word and sentence levels, the political news topic had the highest percentages of euphemistic strategies $(48.07 \%, 1183$ occurrences). This entails that the daily Evro newspaper is mostly written for political purposes more than having economic, social, religious, or sexual orientations. Statistically, there were moderate significant differences (i.e. $\mathrm{V}=.220, \mathrm{p}<0.05$ ) between and within all the news topics and euphemistic strategies. This means that the results obtained were in agreement with the hypothesis proposed and the observed effect of the sample reflects the characteristics of the whole population.

\section{REFERENCES}

Al-Azzeh, Ikram (2010) The Use of Euphemisms by Jordanian Speakers of Arabic. Unpublished Dissertation. Middle East University, Jordan.

Allan, Keith and Burridge, Kate (1991) Euphemism and Dysphemism: Language Used as Shield and Weapon. New York: Oxford University Press.

Allan, Keith. (2012) "X-phemism and Creativity". In Lexis 7: "Euphemism as a Word-Formation Process". Allan, Keith. et al. (Ed.), p. 5-37. Available from https://lexis.revues.org/340/. [Accessed: May 2016].

Ameen, Nizhyar Idrees (2012) تابو د زمانيّ كورديدا: كوفهرا بهدينان وهك نمعانه (Taboo Expressions in Kurdish: Bahdinan Area as a Sample). Unpublished Thesis. College of Arts, University of Duhok.

Baha'ddin, Sadiq (2005) تيديه منيت كوردى (Kurdish Idioms). $2^{\text {nd }}$ ed. Duhok: Spirez Press.

Bakhtiar, Mohsen (2012) "Communicative Functions of Euphemisms in Persian." In The Journal of International Social Research. $5(20)$, p. $7-12$
Baladze, Maka (2013) "Linguistic Peculiarities of Euphemisms in Media Discourse". In Humanities and Social Sciences Review, 2 (4), p. 379-384. Available from http://universitypublications.net/ [Accessed: March 2016].

Beck, S. and Manuel, K. (2008). Practical Research Methods for Librarians and Information Professionals. New York, NY: Neal-Schuman.

Berelson, Bernard (1952). Content Analysis in Communication Research. New York: Hafner.

Bultnick, Bert (1998) Metaphors We Die By: Conceptualizations of Death in English and their Implications for the Theory of Metaphor. Antwerpen: Universiteit Antwerpen.

Burchfield, Robert (1985) "An Outline History of Euphemisms in English.” In D. J. Enright (Ed.), Fair of Speech: The Uses of Euphemisms. Oxford: Oxford University Press. p. 13-31.

Burridge, Kate (2012) "Euphemism and Language Change: The Sixth and Seventh Ages." In Lexis 7: "Euphemism as a WordFormation Process". Allan, Keith. et al. (Ed.), p. 65-92. Available from https://lexis.revues.org/340/. [Accessed: May 2016].

Chadwick, B. A., Bahar, H. M. \& Albrecht, S. L. (1984). "Content Analysis". In B. A. Chadwick et al (Eds.) Social Science Research Methods. New Jersey: Prentice Hall, pp. 239-257.

Cohen, L., Manion, L. and Morrison, K. (2007). Research Methods in Education. 6th ed. London: Routledge.

Cruse, D. (1986) Lexical Semantics. Cambridge: Cambridge University Press.

Crystal, David (2003) The Cambridge Encyclopedia of the English Language. Cambridge: Cambridge University Press.

Denscombe, Martyn (2010). The Good Research Guide. 4th ed. USA: Open University Press.

Fernandez, E. Crespo (2005) "Euphemistic Strategies in Politeness and Face Concerns". In Pragmalingüística, Issue 13, p. 77-86. University of Alicante, Spain.

Fernandez, E. Crespo (2014) "Euphemism and Political Discourse in the British Regional Press". In Brno Studies in English, 40 (1), p. 5-26. Digital Library of the Faculty of Arts, Masaryk University.

Flick, Uwe (1998) An Introduction to Qualitative Research. London: Sage Publishers.

Gomaa, Yasser A. and Shi, Yeli (2012) "Softboiled Speech: A Contrastive Analysis of Death Euphemisms in Egyptian Arabic and Chinese". In GJHSS, 12 (8). USA: Global Journals Inc.

Hojati, Alireza (2012) "A Study of Euphemisms in the Context of English-speaking Media". In International Journal of Linguistics, 4 (4), p. 552-562, Available from http://macrothink.org/ijl/. [Accessed: February 2016].

Jackova, Martina (2010) "Euphemisms in Today's English". Unpublished Dissertation. Tomas Bata University, Zlin, Czech.

Krippendorff, Klaus H. (1967) “An Examination of Content Analysis: A Proposal for a General Framework and an Information Calculus for Message Analytic Situations". Unpublished Dissertation. University of Illinois, USA.

Krippendorff, Klaus H. (2003) Content Analysis: An Introduction to Its Methodology. 2nd ed. London: Sage Publishers.

Lakoff, George and Mark Johnson (1980) Metaphors We Live By. Chicago: University of Chicago Press.

Landis, J. R. and Koch, G. G. (1977). "The Measurment of Observer Agreement for Categorical Data". In Biometrics, 33, p. 159174. Available from https://stattutorials.com/SPSSDATA/. [Accessed: July 2016].

Luke, Douglas A, Caburnay, Charlene A. and Cohen, Elisia L. (2011). "How much is Enough? New Recommendations for Using Constructed Week Sampling in Newspaper Content Analysis of Health Stories". In Communication Methods and Measures, 5 (1), pp. 76-91. Available from https://cphss.wustl.edu/ [Accessed: February 2016].

Lynch, Stacy and Peer, Limor (2002). Analyzing Newspaper Content: A How-to Guide. Readership Institute. Available from 
https://wvdhhr.orgbphtraining/

newspapercontentanalysis.pdf. [Accessed: February 2017].

Mayring, Philipp (2004) “Qualitative Content Analysis”. In Uwe Flick,

E. von Kardoff and I. Steinke (Eds.) A Companion to Qualitative Research. London: Sage Publishers, pp.257-275.

Mohammed, Fakhir O. and Mallow, San'an S. (2012) "The Use of Abbreviations in Northern Kurmanji". In Journal of Duhok University, 15 (1), p. 11-20.

Neuendorf, Kimberly A. and Skalski, Paul D. (2010). "Extending the Utility of Content Analysis via the Scientific Method". University of Hawaii. Available from https://manoa.hawaii.edu/ccpv/workshops/ . [Accessed: September 2016].

Quirk, R., Greenbaun, S., Leech, G., and Svartvik, J. (1972) $A$ Grammar of Contemporary English. London: Longman Group Ltd.

Riffe, D., Stephen, L. and Fico, F. (2014). Analyzing Media Messages: Using Quantitative Content Analysis in Research. $3^{\text {rd }}$ ed. London: Routledge.

Robson, Colin (2002). Real World Research: A Resource for Social Scientists and Practitioner-Researchers. 2nd ed. UK: Blackwell Publishing.
Shekhany, Abdulwahab (2006) فه رهنكى نيديه له زمانى كورديى (A Dictionary of Idioms in Kurdish). Mukiryani Establishment for Research and Publication. Erbil.

Stempel, Guido H. (2003). "Content Analysis". In G. H. Stempel III, D. H. Weaver, \& G. C. Wilhoit (Eds.) Mass Communication Research and Theory. Boston: Allyn \& Bacon, pp. 209-219.

Utts, Jessica M. and Heckard, Robert F. (2007) Mind on Statistics. 3rd ed. USA: Thomson Brooks/Cole.

Warren, Beatrice (1992) "What Euphemisms Tell us about the Interpretation of Words". In Studia Linguistica, 46 (2), p.128-
172
Available
from http:/ http://onlinelibrary.wiley.com/doi/10.1111/j.1467-9582/. [Accessed: June 2016].

Weaver, Dustin A. (2009) "Exemplification in Newspapers: A Content Analysis and Case Studies". Unpublished Thesis. Ohio University, USA.

Weber, R. Phillip (1990). Basic Content Analysis (2nd ed.). Newbury Park, CA: Sage Publications.

\section{APPENDIXES}

Appendix I: List of Kurdish Letters with Examples from English Pronunciation

\begin{tabular}{|c|c|c|c|}
\hline $\begin{array}{l}\text { Kurdish } \\
\text { Letter }\end{array}$ & $\begin{array}{c}\text { English } \\
\text { Pronunciation } \\
\text { (Bald letters } \\
\text { represent the } \\
\text { Kurdish letter) }\end{array}$ & $\begin{array}{c}\text { Kurdish } \\
\text { Letter }\end{array}$ & $\begin{array}{c}\text { English } \\
\text { Pronunciation } \\
\text { (Bald letters } \\
\text { represent the } \\
\text { Kurdish letter) }\end{array}$ \\
\hline 1 & Car & ظ & Villa \\
\hline ب ب & Brother & ق & Quran \\
\hline 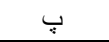 & Play & 5 & Key \\
\hline$ت$ & Ten & $b$ & Good \\
\hline ج & Bridge & $j$ & Play \\
\hline ض & Church & $j$ & Model \\
\hline$\tau$ & Hussein & 5 & Modern \\
\hline$\dot{\tau}$ & Loch & ن & New \\
\hline د & Day & $\circ$ & High \\
\hline J & Pray & $\ddot{0}$ & Rag \\
\hline j & Zoo & 9 & Shot \\
\hline$\dot{j}$ & Pleasure & وَ & Pot \\
\hline س & Save & $ى$ & Sea \\
\hline ش ش & Shine & v & Pet \\
\hline ف & Foot & & \\
\hline
\end{tabular}

Note: This order of the alphabet was recently proposed by Kurdish Academy in Erbil, 2016, as the new standard.

Appendix II: Coding Sheet for Recording the Euphemistic Strategies at Word and Sentence Levels

\begin{tabular}{|l|l|l|l|l|l|l|l|l|l|l|l|l|l|}
\hline \multirow{3}{*}{ News Topics } & \multicolumn{8}{|c|}{ Euphemistic Strategies } \\
\cline { 2 - 11 } & \multicolumn{8}{|c|}{ Sord Level } & \multicolumn{7}{|c|}{ Sentence Level } & \\
\cline { 2 - 11 } & 1 & 2 & 3 & 4 & 5 & 6 & 7 & 8 & 9 & 10 & 11 & 12 & \\
\hline
\end{tabular}




\begin{tabular}{|c|c|c|c|c|c|c|c|c|c|c|c|c|}
\hline & & 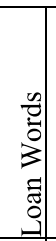 & 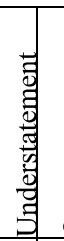 & 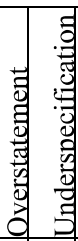 & 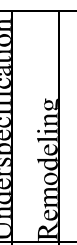 & 章 & 䁨 & & 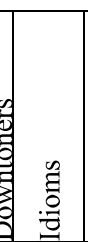 & 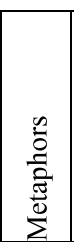 & 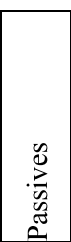 & 丞 \\
\hline 1 & Political & & & & & & & & & & & \\
\hline 2 & Economical & & & & & & & & & & & \\
\hline 3 & Social & & & & & & & & & & & \\
\hline 4 & Medical & & & & & & & & & & & \\
\hline 5 & Sexual & & & & & & & & & & & \\
\hline 6 & Religious & & & & & & & & & & & \\
\hline 7 & Death & & & & & & & & & & & \\
\hline 8 & Sports & & & & & & & & & & & \\
\hline \multicolumn{2}{|c|}{ Total } & & & & & & & & & & & \\
\hline
\end{tabular}

Appendix III: Names of Units and Their Equivalent Representing Codes Used in the Coding Process

\begin{tabular}{|c|c|c|c|c|c|c|c|c|c|c|c|c|c|}
\hline \multirow[t]{2}{*}{ 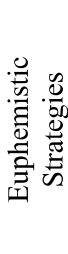 } & Unit & 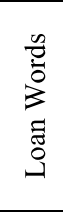 & 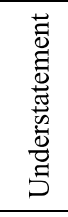 & 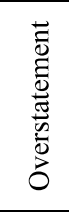 & 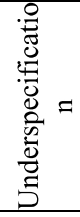 & 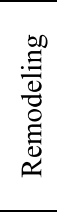 & 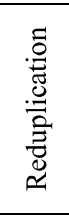 & 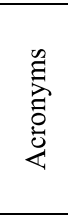 & 䓵 & 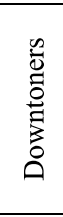 & $\begin{array}{l}\text { ב } \\
.0 \\
.0\end{array}$ & $\begin{array}{l}\frac{n}{0} \\
\frac{0}{0} \\
\frac{\pi}{0} \\
\frac{\pi}{2}\end{array}$ & 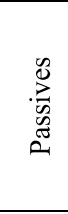 \\
\hline & Code & ES1 & ES2 & ES3 & ES4 & ES5 & ES6 & ES7 & ES8 & ES9 & ES10 & ES11 & ES12 \\
\hline
\end{tabular}

\begin{tabular}{|c|c|c|c|c|c|c|c|c|c|}
\hline \multirow[t]{2}{*}{$\begin{array}{l}\frac{n}{0} \\
\stackrel{0}{0} \\
\stackrel{n}{1} \\
\tilde{b} \\
z\end{array}$} & Unit & 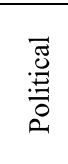 & 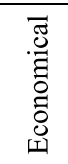 & $\begin{array}{l}\bar{\pi} \\
\frac{\pi}{8} \\
0 \\
0\end{array}$ & 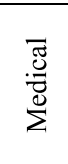 & 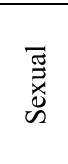 & 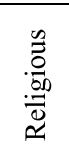 & $\begin{array}{l}\text { Е } \\
\text { Ф̃ }\end{array}$ & $\frac{.00}{.00}$ \\
\hline & Code & NT1 & NT2 & NT3 & NT4 & NT5 & NT6 & NT7 & NT8 \\
\hline
\end{tabular}

\section{Note: ES = Euphemistic Strategy, NT $=$ News Topic ENDNOTES}

1. For more details about the linguistic devices and tactics used to form euphemisms, see Fernandez, E. C. (2014)." Euphemism and Political Discourse in the British Regional Press". In Brno Studies in English. Vol. 40, No. 1, pp. 8-14. Digital Library of the Faculty of Arts, Masaryk University. 2. For detailed information about underspecification and its relation with overstatement and understatement, refer to Allan, Keith. (2012). "X-phemism and Creativity". In Lexis 7: "Euphemism as a Word-Formation Process". Edited by Allan, Keith. et al. pp. 5-37.

3. There is a difference between the two words مةمك (breasts) and ضضك (breasts) though they both refer to the same part of women's body, i.e. breasts. The former is used when one talks about the breasts in a sexual view. In contrast, the latter is mainly related to feeding babies with milk.

4. Crystal (2003: 120) classifies abbreviations into acronyms, initialisms, clippings, blending, awkward cases and facetious forms. All of them function as replacing longer terms with simpler ones.

5. For Quirk et al. (1972: 452-458) downtoning adverbs and phrases fall under the category of downtoners, which they classify into four groups: (1) compromisers (rather, sort of, kind of), (2) diminishers (partly, slightly, to some extent), (3) minimizers (possibly, hardly, in the least) and (4) approximators (almost, practically, virtually).

6. These examples are translated word-by-word first so that the exact literary meaning is clear.

7. For more details on how people think in metaphors, depending on everyday experiences, refer to Lakoff, George and Mark Johnson (1980). Metaphors We Live By. Chicago: University of Chicago Press. Pp. 47-52

8. The corpus examples in his book, A Dictionary of Idioms in Kurdish, are in Sorani, a dialect spoken in Hawler and Sulaimani areas within Kurdistan Region, Iraq. However, for the purpose of the current study, the researcher listed some equivalent euphemistic expressions related to death in the BD. 9. Berelson's original definition of the CA is an example of the first kind. For detailed explanations on the $\mathrm{CA}$ as a research tool, see Berelson, Bernard (1952) Content Analysis in Communication Research. New York: Hafner.

10. Krippendorff (2003: 29-39) claims that the CA is like a methodological framework where there are six general requirements for doing any content analysis: (1) a body of text, (2) research questions, (3) context, (4) analytical constructs, (5) inferences and (6) validating evidences.

11. Evro is a five-day operation daily newspaper issued in Duhok City. It was issued for the first time in 2003 as a weekly newspaper; however, it became daily in 2009. The newspaper, which is considered the mouthpiece of families, covers various news topics including politics, health, science, economy, culture, society, sports, etc. Evro was selected for the current research sampling because it has the largest circulation (25002700 issues per day) among the rest of journals and periodicals in Badinan area (Bedel, Naji, personal interview, March 2, 2017).

12. According to Evro sample, being a five-day operation newspaper, 126 issues, which do not have publications at all, were excluded due to off days and holidays.

13. For more details about reliability and validity in both quantitative and qualitative research analyses, refer to Cohen et al (2007: 146-150). 


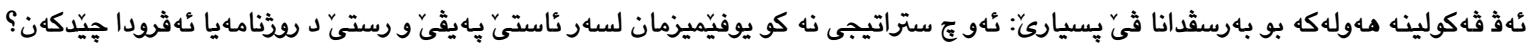

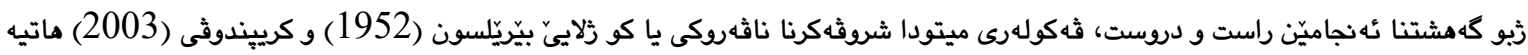

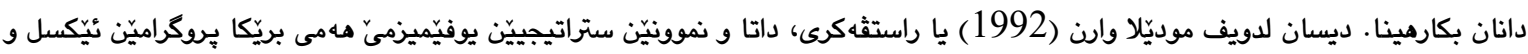

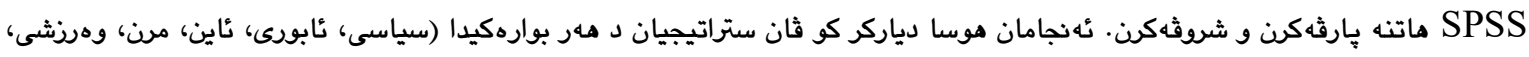

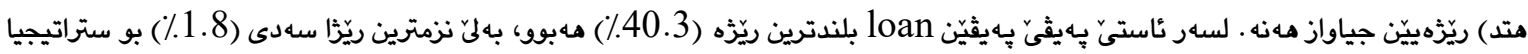

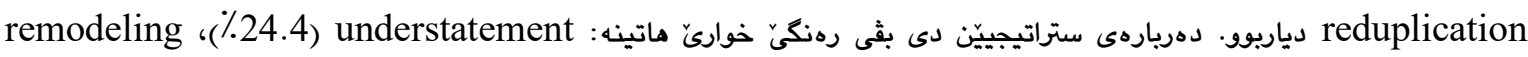

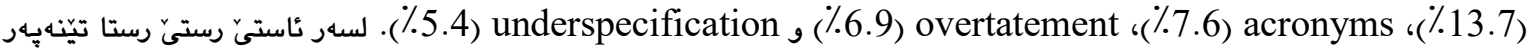

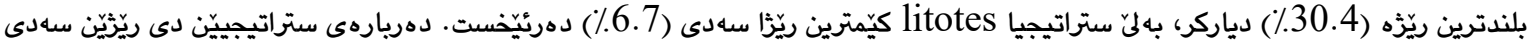

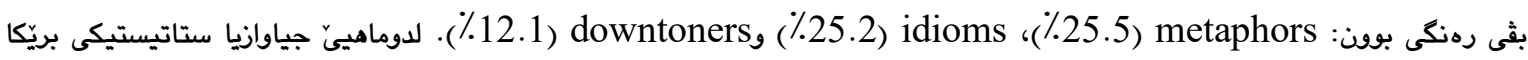

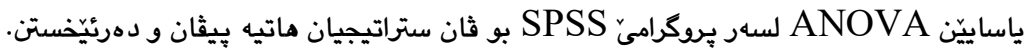

الملخص:

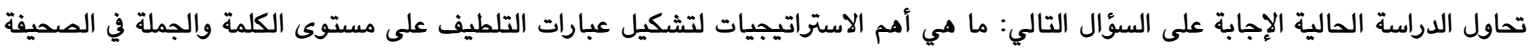

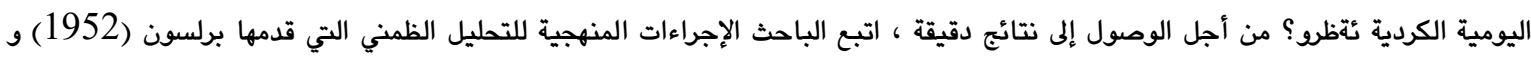

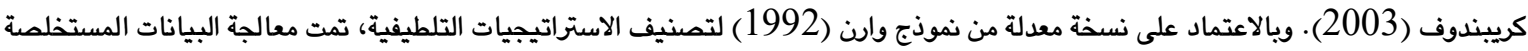

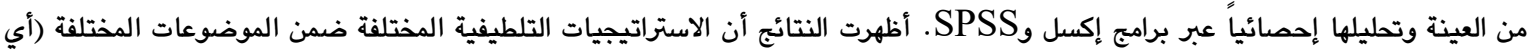

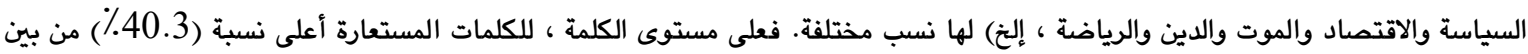

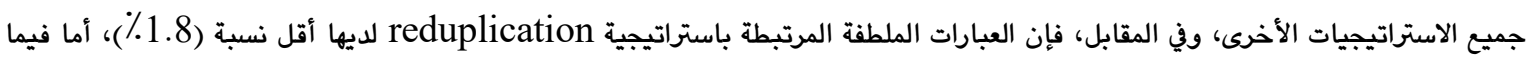

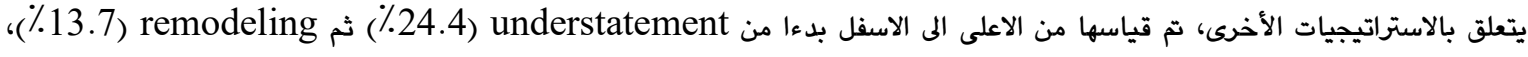
acronyms

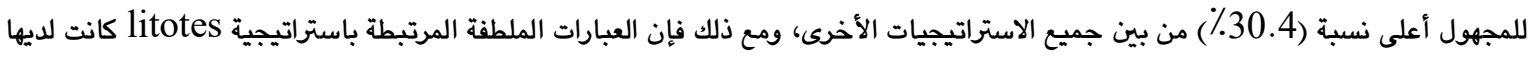

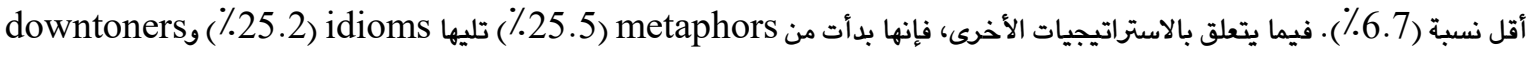

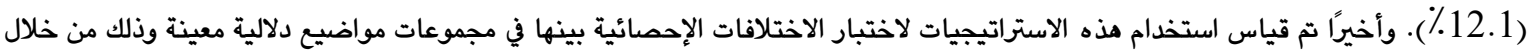

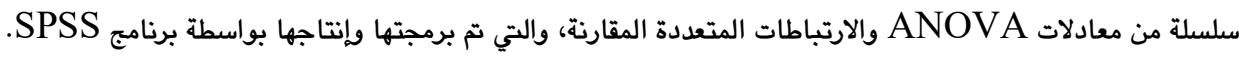

